\title{
Epidemiological study of patients infected with scabies caused by Sarcoptes scabiei in Al-Najaf Governorate, Iraq.
}

\author{
Ali A. Mohy*, Saleem Khteer Al-Hadraawy, Ahmed Abduljabbar Jaloob Aljanaby \\ Department of Biology, Faculty of Science, University of Kufa, Iraq
}

\begin{abstract}
The aim of the current study was to epidemiological detection of patients infected with scabies caused by Sarcoptes scabiei during the period from March 2017 to February 2018 in Iraq, Al-Najaf Governorate. A total of 1112 patients were infected with scabies, $602(54.1 \%)$ were men and $501(45.9 \%)$ were female and 419 patients $(37.7 \%)$ were lived in urban areas and 693 patients $(62.3 \%)$ were lived in rural areas. Age group 31-40 y old was the most prevalent group (379 patients, 34\%) infected with scabies. February 2018 was the highest month in infection (187 patients, 16.8\%) and May 2017 was the lowest month in infection (25 patients, $2.2 \%$ ). In conclusions: In Iraq, there are high numbers of individuals infected with scabies without any health care especially in rural areas. Scabies is more prevalent in cold and warmth seasons in males as well as females among age group 30-40 y old. Therefore, scabies is still an important health problem in Iraq as a neglected disease.
\end{abstract}

Keywords: Scabies, Epidemiology, Urban, Rural, Age groups, Najaf, Iraq.

Accepted on May 21, 2018

\section{Introduction}

Scabies is one of the most important skin diseases worldwide particularly in developing countries, caused by mite Sarcoptes scabiei $[1,2]$. Sexually transmitted is the main way of infection and is a common between family members [3]. Patients infected with scabies suffer from skin redness and severe itching in different body parts such as arms, legs and between the thighs [4,5]. Most patients infected with this disease are lived in rural areas without health care and without health awareness [6-8]. About more than 100 million patients infected with scabies worldwide $[9,10]$. Diagnosis of scabies is depend on many clinical and physical parameters include; the presence of mite Sarcoptes scabiei or it products, strong itching and skin inflammation [11]. Scabies infect both male and female in different age groups, and it is common in tropical climate countries, in poor people who live in rural areas $[12,13]$. In Iraq, there is no recent studies focus on the prevalence of scabies in urban and rural areas. Therefore, this research designed to epidemiological study of patients infected with scabies caused by Sarcoptes scabiei during 12 months and compare between different parameters include; sex, age groups, seasons and general culture in Iraq.

\section{Materials and Methods}

\section{Patients}

This is epidemiological study was done in Al-Najaf Governorate, Iraq. During the period from March 2017 to February 2018, a total of 1112 patients (male and female) infected with scabies were included in this study, age ranges between 10 to $70 \mathrm{y}$ old lived in urban and rural areas. All patients infected with scabies caused by Sarcoptes scabiei were diagnosed according to physical exam and inspecting the affected area of skin or removing a $S$. scabiei from the skin with a needle and take a scrape off a small section of skin to obtain a tissue sample and examined this sample under a microscope to confirm the presence of scabies mites or their eggs [14].

\section{Statistical analysis}

Statistical analysis was done according to percentages to compare between samples using SPSS V.9 computer software [15].

\section{Results}

Out of 1112 patients, 602 (54.1\%) were males and 501 (45.9\%) were female (Figure1). According to area of infection, the results demonstrated that there were 419 patients $(37.7 \%)$ were lived in urban areas and 693 patients $(62.3 \%)$ were lived in rural areas (Figure 2).

Age group 31-40 y old was the most prevalent group (379 patients, 34\%) infected with scabies (Table 1) among this group, 201 males (53\%) and 178 females (47\%) (Figure 3).

February 2018 was the highest month in infection (187 patients, 16.8\%) and May 2017 was the lowest month in infection (25 patients, 2.2\%) (Figures 4 and 5). Profile of 1112 patients infected with scabies is mentioned in Table 2. 


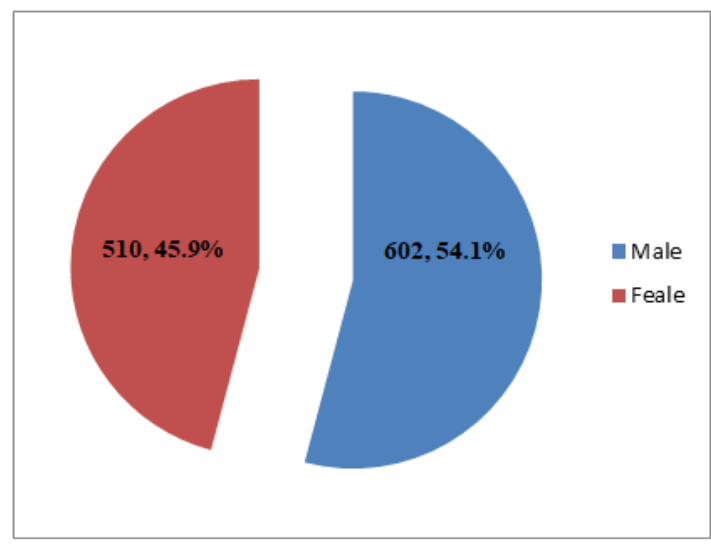

Figure 1. Numbers and percentages of patients infected with scabies in Al-Najaf Governorate, Iraq, during the period from March 2017 to February 2018 according to gender. $N=1112$ patients.

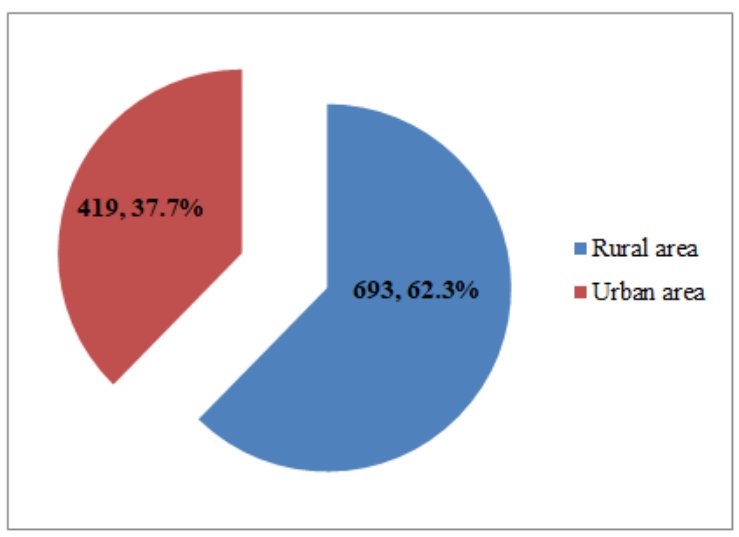

Figure 2. Distribution of patients infected with scabies in AL-Najaf Governorate, Iraq, during the period from March 2017 to February 2018 according to areas of residence. $N=1112$ patients.

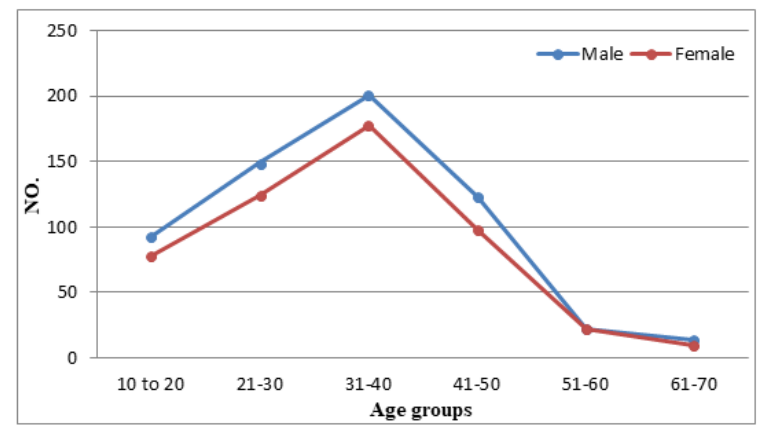

Figure 3. Numbers and percentages of patients infected with scabies in AL-Najaf Governorate, Iraq, during the period from March 2017 to February 2018 according to areas of age groups and gender. $N=1112$ patients.

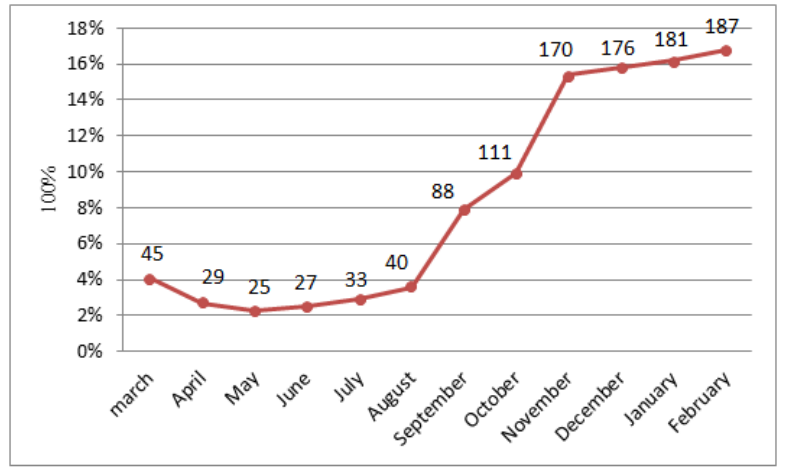

Figure 4. Numbers and percentages of patients infected with scabies in Al-Najaf Governorate, Iraq, during the period from March 2017 to February 2018. N=1112 patients.

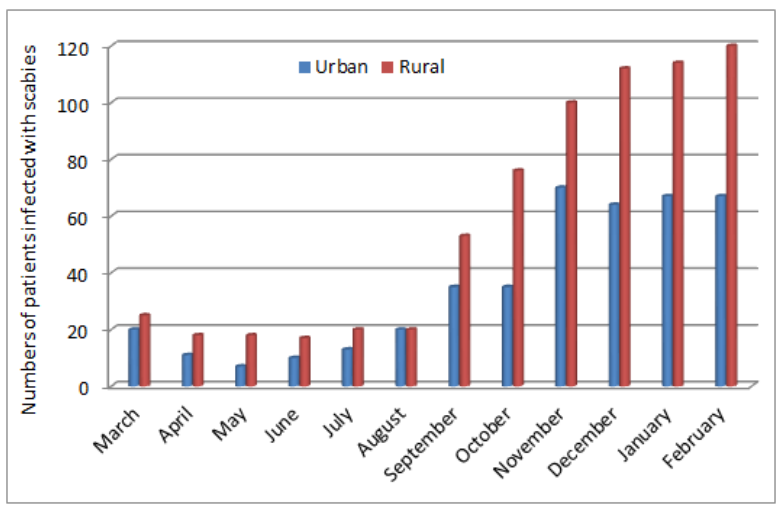

Figure 5. Monthly distribution of patients infected with scabies in AlNajaf Governorate, Iraq, during the period from March 2017 to February 2018 according to areas of residence. $N=1112$ patients.

Table 1. Distribution of patients infected with scabies in AL-Najaf Governorate, Iraq, during the period from March 2017 to February 2018 according to age groups. $N=1112$ patients.

\begin{tabular}{lll}
\hline Age groups & No. & $\mathbf{1 0 0 \%}$ \\
\hline 44105 & 171 & 15.3 \\
\hline $21-30$ & 273 & 24.6 \\
\hline $31-40$ & 379 & 34 \\
\hline $41-50$ & 221 & 20 \\
\hline $51-60$ & 44 & 4 \\
\hline $61-70$ & 24 & 2.1 \\
\hline Total & 1112 & 100 \\
\hline
\end{tabular}

Table 2. Profile of 1112 patients infected with scabies in Al-Najaf Governorate, Iraq, during the period from March 2017 to February 2018.

\begin{tabular}{llllllll}
\hline \multirow{2}{*}{ Age groups } & \multicolumn{3}{l}{ Urban area $419(37.7 \%)$} & & Rural area $693(62.3 \%)$ & \\
\cline { 2 - 7 } & Male & Female & Total $(100 \%)$ & Male & Female & Total (100\%) \\
\hline
\end{tabular}




\begin{tabular}{|c|c|c|c|c|c|c|}
\hline 44105 & 31 & 23 & $54(12.8)$ & 62 & 55 & $117(16.9)$ \\
\hline $21-30$ & 61 & 49 & $110(26.5)$ & 88 & 75 & $163(23.5)$ \\
\hline $31-40$ & 78 & 63 & $141(33.6)$ & 123 & 115 & $238(34.3)$ \\
\hline $41-50$ & 53 & 39 & $92(21.9)$ & 70 & 59 & $129(18.7)$ \\
\hline $51-60$ & 9 & 5 & $14(3.3)$ & 13 & 17 & $30(4.3)$ \\
\hline $61-70$ & 5 & 3 & $8(1.9)$ & 9 & 7 & $16(2.3)$ \\
\hline Total & $237(56.5)$ & $182(43.5)$ & 419 (100) & $365(52.7)$ & $328(47.3)$ & $693(100)$ \\
\hline \multirow{2}{*}{ Months } & \multicolumn{3}{|l|}{ Urban area $419(37.7 \%)$} & \multicolumn{3}{|l|}{ Rural area $693(62.3 \%)$} \\
\hline & Male & Female & Total $(100 \%)$ & Male & Female & Total $(100 \%)$ \\
\hline March 2017 & 15 & 5 & $20(4.7)$ & 15 & 10 & $25(3.3)$ \\
\hline April 2017 & 5 & 6 & $11(2.6)$ & 10 & 8 & $18(2.6)$ \\
\hline May 2017 & 4 & 3 & $7(1.6)$ & 8 & 10 & $18(2.6)$ \\
\hline June 2017 & 8 & 2 & $10(2.3)$ & 8 & 9 & $17(2.5)$ \\
\hline July 2017 & 8 & 5 & $13(3.2)$ & 14 & 6 & $20(2.9)$ \\
\hline August 2017 & 12 & 8 & $20(4.7)$ & 7 & 13 & $20(2.9)$ \\
\hline September 2017 & 23 & 12 & $35(8.4)$ & 28 & 25 & $53(7.7)$ \\
\hline October 2017 & 20 & 15 & $35(8.4)$ & 41 & 35 & $76(11)$ \\
\hline November 2017 & 34 & 36 & 70 (16.8) & 54 & 46 & $100(14.5)$ \\
\hline December 2017 & 33 & 31 & $64(15.3)$ & 52 & 60 & $112(16.2)$ \\
\hline January 2018 & 37 & 30 & $67(16)$ & 59 & 55 & $114(16.5)$ \\
\hline February 2018 & 38 & 29 & $67(16)$ & 69 & 51 & $120(17.3)$ \\
\hline Total & $237(56.5)$ & $182(43.5)$ & $419(100)$ & $365(52.7)$ & $328(47.3)$ & $693(100)$ \\
\hline
\end{tabular}

\section{Discussion}

Scabies is considered as one of the most prevalent skin infections in third worlds countries. About more than 350 cases occurring every year; most these cases are incidence in developing countries in poor peoples who live in rural and crowded areas characterized with tropical climate. In this study, out of 1112 , there were 602 patients $(54.1 \%)$ were men and 501 patients $(45.9 \%)$ were female infected with scabies. Almost, males were equally affected as females in this study approximately ratio of $1: 1$. These results are in agreement with Nair et al. [8] that they are proved there were 52 patients $(50.98 \%)$ were males and 50 patients $(49.01 \%)$ were females in Gujarat, India. Also, Mason et al. [7] demonstrated that out of total 515870 patients infected with scabies in Solomon Islands there were $51.3 \%$ males and $48.7 \%$ females. In Iraq, in Tikrit Governorate in 2009, Alsamarai [16] proved that out of total 11194 patients infected with scabies there were $13.5 \%$ and $8.6 \%$ were male and female, respectively. While, Sharquie [17] found in his study in Baghdad, Iraq, out of total 97 patients infected with scabies there were $58(59.8 \%)$ males and 39 (40.2\%) females. Almost, rural areas are the most infected regions with different bacterial and parasitic infections; this may be due to the absence of health awareness and enough health care $[18,19]$. Our results indicated that rural areas were more than urban areas in scabies infection with percentage $62.3 \%$ and $37.7 \%$, respectively. These results are in agreement with Hegab et al. [20] when they are proved that out of total of 2104 school children were infected with scabies there were 862 $(41 \%)$ were lived in urban areas and 1242 (59\%) were lived in rural areas in Kafr El-Sheikh in Egypt. Recently, Walker et al. [21] in southern Ethiopia showed that peoples who lived in poor quality and crowded areas were more infected with scabies as compared with those lived in good quality areas. The incidence of skin disease such as scabies in poor and low middle income communities in different countries are a significant public health problem because of the poor health awareness, absence of personal hygiene and general culture $[3,9]$. In the current study, the most common age group infected with scabies was $31-40$ y old 379 patients $(34 \%)$ in urban area and 141 patients $(33.6 \%)$ and in rural area 238 patients $(34.3 \%)$. This result is in agreement with Alsamarai [16] in Iraq when he showed that there were 42 patients $(31.8 \%)$ infected with scabies were among age group 30-44 y. Also, Ramachandra et al. [22] in India showed that $30-40 \%$ of patients were infected with scabies were in age group $>30$ y old. While, Hamarsheh et al. [23] found that $<10$ y group was the more prevalent among age groups in Palestinian territories 
with percentage $27 \%$. We can explain the result of this study, is may be due to contact between married men and women in same family lead to transfer this mite during sexually contact from husbands to wives. Climate is one of the most important factors that play an important role in scabies incidence worldwide [24]. Iraq is a tropical country characterized by high temperature between $30^{\circ} \mathrm{C}$ to $40^{\circ} \mathrm{C}$ throughout the year. Our results proved that scabies was most prevalent in February (187 patients, $16.8 \%$ ) when temperature range between $35^{\circ} \mathrm{C}$ to $20^{\circ} \mathrm{C}$. These results are in agreement with many studies [25-27]. There are positive association between temperature and humidity and incidence of scabies, because of these conditions provide suitable factors for parasite growth and survival in different parts of the human body [28,29]. Scabies is consider as a one of the most prevalent skin disease in tropical areas particularly in developing countries suffering from poverty and a significant increase in the population [30-32]. Although the World Health Organization (WHO) classified scabies as a neglected disease, but until now it has not developed formal programs for scabies control in developing countries [33]. Therefore, we need more health awareness programs and health care in developing countries particularly in rural areas to prevent spreading this disease.

\section{Conclusion}

In Iraq, there are high numbers of individuals infected with scabies without any health care especially in rural areas. Scabies is more prevalent in cold and warmth seasons in males as well as females among age group 30-40 y old. Therefore, Scabies is still an important health problem in Iraq as a neglected disease.

\section{References}

1. Fuller LC. Epidemiology of scabies. Curr Opin Infect Dis 2013; 2: 123-126.

2. Romani L, Whitfeld MJ, Koroivueta J, Kama M, Wand H, Tikoduadua L, Tuicakau M, Koroi A, Ritova R, Andrews R, Kaldor JM, Steer AC. The epidemiology of scabies and impetigo in relation to demographic and residential characteristics: baseline findings from the skin health intervention Fiji trial. Am J Trop Med Hyg 2017; 97: 845-850.

3. Hay RJ, Augustin M, Griffiths CE, Sterry W. Board of the international league of dermatological $s$, the grand challenges consultation $\mathrm{g}$. The Global Challenge for Skin Health. Br J Dermatol 2015; 172: 1469-1472.

4. Khatoon N, Khan A, Azmi MA, Khan A, Shaukat SS. Report-most common body parts infected with scabies in children and its control. Pak J Pharm Sci 2016; 5: 1715-1717.

5. Sánchez-Borges M, González-Aveledo L, Capriles-Hulett A, Caballero-Fonseca F. Scabies, crusted (Norwegian) scabies and the diagnosis of mite sensitisation. Allergol Immunopathol 2017; 0301-0546.

6. Kalu EI, Wagbatsoma V, Ogbaini-Emovon E, Nwadike VU, Ojide CK. Age and sex prevalence of infectious dermatoses among primary school children in a rural South-Eastern Nigerian community. Pan Afr Med J 2015; 20: 182 .

7. Mason DS, Marks M, Sokana O, Solomon AW, Mabey DC, Romani L, Kaldor J, Steer AC, Engelman D. The prevalence of scabies and impetigo in the Solomon Islands: A population-based survey. PLoS Negl Trop Dis 2016; 10: e0004803.

8. Nair PA, Vora RV, Jivani NB, Gandhi SS. A study of clinical profile and quality of life in patients with scabies at a rural tertiary care centre. J Clin Diagn Res 2016; 10: WC01-WC05.

9. Hay RJ, Johns NE, Williams HC, Bolliger IW, Dellavalle RP, Margolis DJ, Marks R, Naldi L, Weinstock MA, Wulf SK, Michaud C, J L Murray C, Naghavi M. The global burden of skin disease in 2010: An analysis of the prevalence and impact of skin conditions. J Invest Dermatol 2014; 134: 1527-1534.

10. Marotta M, Toni F, Dallolio L, Toni G, Leoni E. Management of a family outbreak of scabies with high risk of spread to other community and hospital facilities. Am J Infect Control 2018; 31305-31306.

11. Worth C, Heukelbach J, Fengler G, Walter B, Liesenfeld $\mathrm{O}$, Feldmeier H. Impaired quality of life in adults and children with scabies from an impoverished community in Brazil. Int J Dermatol 2012; 51: 275-282.

12. Anderson KL, Strowd LC. Epidemiology, diagnosis, and treatment of scabies in a dermatology office. J Am Board Fam Med 2017; 30: 78-84.

13. Dhana A, Yen H, Okhovat JP, Cho E, Keum N, Khumalo NP. Ivermectin versus permethrin in the treatment of scabies: A systematic review and meta-analysis of randomized controlled trials. J Am Acad Dermatol 2018; 78: 194-198.

14. Chosidow O. Clinical practices. Scabies. N Engl J Med 2006; 354: 1718-1727.

15. Aljanaby AAJ, Medhat AR. Research article prevalence of some antimicrobials resistance associated-genes in Salmonella typhi isolated from patients infected with typhoid fever. J Biol Sci 2017; 17: 171-184.

16. Alsamarai AM. Frequency of scabies in Iraq: survey in a dermatology clinic. J Infect Dev Ctries 2009; 3: 789-793.

17. Sharquie KE, Al-Rawi JR, Noaimi AA, Al-Hassany HMJ. Treatment of scabies using $8 \%$ and $10 \%$ topical sulfur ointment in different regimens of application. Drugs Dermatol 2012; 11: 357-364.

18. Gakoué DZ, Tiembré I. Epidemiological aspects of genital ulcers at the STI center of the National Institute of public hygiene (Abidjan, Côte d'Ivoire) 2008 to 2010. Med Sante Trop 2017; 27: 90-94.

19. Al-Hadraawy SK, Hessen HB. Hematological and epidemiological study for patients infected with scabies. J Pharm Sci Res 2017; 9: 897-900.

20. Hegab DS, Kato AM, Kabbash IA, Dabish GM. Scabies among primary schoolchildren in Egypt: sociome dical environmental study in Kafr El 
Sheikh administrative area. Clin Cosmet Investig Dermatol 2015; 8: 105-111.

21. Walker SL, Lebas E, De Sario V, Deyasso Z, Doni SN, Marks M, Roberts CH, Lambert SM. The prevalence and association with health-related quality of life of tungiasis and scabies in schoolchildren in southern Ethiopia. PLoS Negl Trop Dis 2017; 11: e0005808.

22. Ramachandra Reddy D, Ramachandra Reddy P. Nodular scabies: a classical case report in an adolescent boy. J Parasit Dis 2015; 39: 581-583.

23. Amro A, Hamarsheh O. Epidemiology of scabies in the West Bank, Palestinian Territories (Occupied). Int J Infect Dis 2012; 16: 117-120.

24. Liu JM, Wang HW, Chang FW, Liu YP, Chiu FH, Lin YC, Cheng KC, Hsu RJ. The effects of climate factors on scabies. A 14-year population-based study in Taiwan. Parasite 2016; 23: 54.

25. Chen CH, Kou YR, Chen CS, Lin HC. Seasonal variation in the incidence of spontaneous pneumothorax and its association with climate: a nationwide population-based study. Respirology 2010; 15: 296-302.

26. Lin KJ, Lin PH, Chu SH, Chen HW, Wang TM, Chiang YJ, Liu KL, Wang HH. The impact of climate factors on the prevalence of urolithiasis in Northern Taiwan. Biomed J 2014; 37: 24-30.

27. Dayrit JF, Bintanjoyo L, Andersen LK, Davis MDP. Impact of climate change on dermatological conditions related to flooding: update from the International Society of Dermatology Climate Change Committee. Int J Dermatol 2018.

28. Bezirtzoglou $\mathrm{C}$, Dekas $\mathrm{K}$ and Charvalos $\mathrm{E}$. Climate changes, environment and infection: facts, scenarios and growing awareness from the public health community within Europe. Anaerobe 2011; 17: 337-340.
29. Pérez JM, Serrano E, Soriguer RC, González FJ, Sarasa M, Granados JE, Cano-Manuel FJ, Cuenca R, Fandos P. Distinguishing disease effects from environmental effects in a mountain ungulate: seasonal variation in body weight, hematology, and serum chemistry among Iberian ibex (Capra pyrenaica) affected by sarcoptic mange. J Wildl Dis 2015; 51: 148-156.

30. Hotez PJ, Molyneux DH, Fenwick A, Kumaresan J, Sachs SE, Sachs JD, Savioli L. Control of neglected tropical diseases. N Engl J Med 2007; 357: 1018-1027.

31. Engelman D, Kiang K, Chosidow O, McCarthy J, Fuller C, Lammie P, Hay R, Steer A. Members of the international alliance for the control of scabies. Toward the global control of human scabies: introducing the international alliance for the control of scabies. PLoS Negl Trop Dis 2013; 7: e2167.

32. Currie BJ. Scabies and global control of neglected tropical diseases. N Engl J Med 2015; 373: 2371-2372.

33. WHO. Investing to overcome the global impact of neglected tropical diseases: third WHO report on neglected tropical diseases. World Health Organization, Geneva 2015.

\section{*Correspondence to}

Ali A. Mohy

Department of Biology

Faculty of Science

University of Kufa

Iraq 